\title{
Bank Efficiency Evaluation: Evidence from a Panel of Romanian Banks
}

\author{
Angela Roman and Alina Camelia Șargu \\ Department of Economics and Business Administration, Faculty of Economics and Business \\ Administration, Alexandru Ioan Cuza University, lasi, Romania
}

\begin{abstract}
The focus of our research is on the Romanian banking sector, analysing if, over the period 2002 to 2009 , foreign banks have been more efficient than their domestic peers, as foreign banks can benefit from the experience and superior know-how of their parent banks and thus achieve a superior organisation and management process. To reach this aim, we have used the Data Envelopment Analysis approach, estimating the cost, allocative, technical, pure technical and scale efficiencies; and afterwards we have conducted also a series of parametric and nonparametric tests in order to establish if foreign and domestic banks are coming from the same population. The results of the paper underline the fact that in the Romanian banking market, foreign banks are truly more efficient than the domestic ones for being able to better use their advantages and obtain a higher productivity of their inputs. Moreover, during the researched period the efficiency of the banking sector has not been improved, mainly as a consequence of the financial crisis.
\end{abstract}

Keywords: Romanian banks, Data Envelopment Analysis, cost efficiency.

\section{Introduction}

The role of foreign banks in the banking sectors of the new member states represents an ongoing debate, Romania being no exception to this. Most of the early transition governments of this country promoted the idea that foreign banks should have a minimal presence in the national market, as it was considered that the banking sector should remain national at least in the first part of 1990 . Between 1990 and 1997, foreign banks could be present in the Romanian banking market only as greenfield investments or through the acquisition of distressed banking institutions, having the possibility to take only minority shares during the privatisation process. The aspiration to acquire EU membership provided the optimal incentive for the governments to raise the restrictions on foreign banks entry and allowed these institutions the possibility to participate in the privatisation process. As a result of these policies, the share of total banking assets owned by foreign banks has increased in Romania from $15,2 \%$ in 1998 to $77,9 \%$ in 2009 (NBR, 1998; NBR, 2009).

The main body of literature regarding the efficiency and the role of the foreign banks is focused primarily on the US and to a smaller degree on Europe (Berger and Humphrey, 1997). Most studies underline the fact that in developed banking sectors foreign banks tend to register a lower degree of efficiency than domestic banks. Despite this fact, there were some cases where foreign banks from certain countries managed to be more efficient that the domestic banks (Berger and al., 2000). Even if the literature on this subject is relatively smaller in the case of new European Union member states than the one dedicated to the EU-15 countries, there are several studies which support the idea that foreign banks in these countries are

Copyright (C) 2012 Angela Roman and Alina Camelia Șargu. This is an open access article distributed under the Creative Commons Attribution License unported 3.0, which permits unrestricted use, distribution, and reproduction in any medium, provided that original work is properly cited. Contact author: Alina Camelia Șargu E-mail: s_alina_camelia@yahoo.com 
more efficient than domestic banks (Grigorian and Manole, 2002; Hasan and Marton, 2003; Havrylchyk, 2005; Dardac and Boitan, 2008; Toçi, 2009). A much argued reason for these developments is represented by the fact that foreign banks are entering developing and emerging markets for different reasons, aiming not only to follow their costumers but also to exploit local opportunities (Clarke et al., 2001).

Taking these into account, the aim of this paper is to investigate if foreign banks present in the Romanian banking market between 2002 and 2009 have been more efficient than their domestic peers, as foreign banks can benefit from the experience and superior know-how of their parent banks and thus achieve a superior organisation and management process.

In order to achieve this, we will use a Data Envelopment Analysis estimating the cost, allocative, technical, pure technical and scale efficiency. Afterwards, we will carry out a series of parametric and nonparametric tests in order to establish if foreign and domestic banks are coming from the same population.

The present research is different from other studies on this subject as it covers almost $91 \%$ of the total Romanian banking assets making it one of the most comprehensive studies to date in this sector.

The results of our analysis underline the fact that foreign banks are more efficient than domestic banks in the case of Romania, these results being in line with most of the results obtained by the studies undertaken in the case of developing and emerging economies.

In order to achieve the proposed aim, the research is structured as follows: the second part of the research is dedicated to a literature review regarding the efficiency of the banking sector in developing and emerging economies. In part three, we present the methodology that we have used in our study. Part four underlines the data used in this research, while part five presents the empirical results obtained. Part six, the last part of the research, provides the concluding remarks.

\section{Literature Review Regarding the Efficiency of the Banking Sector in Developing and Emerging Economies}

Most of the literature regarding cost efficiency issues is focused on the case of the United States and other developed economies (see: Berger and Humphrey, 1997; Goddard et al, 2001, Weill, 2004; Angelidis and Lyroudi, 2006). There are also a series of studies which are focused on the case of the developing and emerging economies, but their number is still relatively low. Most of these studies are focused on the Asian economies, where countries like Thailand (Sufian and Habibullah, 2010), Korea (Sufian, 2011), Singapore (Rezvanian and Mehdian, 2002), Pakistan (Hardy and Bonaccorsi di Patti, 2001) and India (Debasish, 2006) have been extensively analysed. The interesting dynamic of the Turkish banking system also provided an intriguing research ground (Isik and Hassan, 2002, Aydin et al., 2009). On the other hand, there are also several studies which are focused on the case of the countries from Central and Eastern Europe and the Commonwealth of Independent States (Kraft and Tirtiroglu, 1998; Opiela, 2001; Mertens and Urga, 2001; Grigorian and Manole, 2002; Hasan and Marton, 2003; Bonin et al, 2005; Dardac and Boitan, 2008; Toçi, 2009).

Most of the studies undertaken so far tend to agree on the functions performed by banks and therefore are using the intermediation approach (Kraft and Tirtiroglu, 1998; Rezvanian and Mehdian, 2002; Isik and Hassan, 2002; Bonin et al., 2005). There are also several studies which try to combine the production and intermediation approach considering purchased funds as both input and output (Hasan and Marton, 2003) or by using a model of banking technology which comprises two stages: the production and then the intermediation stage (Denizer et al, 2000). 
Regarding the appropriate estimation methodology which should be used, there has been no consensus reached in the last years. Approximately half of the studies on this subject use Data Envelopment Analysis (Grigorian and Manole, 2002; Rezvanian and Mehdian, 2002; Toçi, 2009), while there are also some which use the Stochastic Frontier Analysis (Kraft and Tirtiroglu, 1998; Mertens and Urga, 2001; Hasan and Marton, 2003; Bonin et al., 2005) or the Distribution Free Approach (Hardy and Bonaccorsi di Patti, 2001; Opiela, 2001). Some studies make use of both parametric and non-parametric approaches in order to ensure a higher robustness of the results (Isik and Hassan, 2002; Rezvanian and Mehdian, 2002). Taking into account that the macroeconomic landscape in which banks activate in developing and emerging economies is very dynamic, most studies estimate separate frontiers for each analysed year, providing through this approach also hindsight regarding the way in which the liberalisation, deregulation and in some cases the European integration process have affected the efficiency of the banking sector. There were also several cases where we needed to perform estimation on the panel data, as there were a limited number of observations available in Bankscope and third party sources.

Taking into account the empirical results of these studies, it can be concluded that the cost efficiency of banks in the case of developing and emerging economies tends to be lower and these banks are also having higher yearly fluctuations than in the case of the developed economies. Thus, in the case of Turkey, the cost efficiency of banks was $78,2 \%$ in 1988 and decreased to $68,5 \%$ by 1996 (Isik and Hassan, 2002), whereas in the case of Pakistan during the prereform period banks efficiency was $48,5 \%$ rising in the post-reform period to $72,8 \%$ (Hardy and Bonaccorsi di Patti, 2001).

By analysing the efficiency of foreign and domestic banks, these studies have provided evidence that foreign banks have been able to use their advantages and managed to register a higher level of efficiency than their domestic peers
(Bhattacharyya et al., 1997; Isik and Hassan, 2002; Hasan and Marton, 2003; Bonin et al., 2005). Some of these studies have tested also if the foreign and domestic banks are from the same population in order to establish if they should use a common or separate frontier in the analysis. In general, both parametric and non-parametric tests failed to reject the null hypothesis regarding the fact that foreign and domestic banks are coming from the same population.

\section{Methodology}

The debate regarding the way in which cost-efficiency should be measured in the case of the banking institutions is a longstanding process, which is far from coming to a universal solution. The main focus of the debate is represented by the methodology which should be used in order to construct a frontier that will take into account the best practiced banks so that the rest of the sample could be measured coherently against this frontier. So far, the methodology used by most of the studies in this matter can be divided into econometric models which use Stochastic Frontier Analysis, the Thick Frontier Approach, the Distribution Free Approach and linear programming technique, namely Data Envelopment Analysis.

In order to measure the evolution of the Romanian banks, we have used the Data Envelopment Analysis (DEA) approach, this method being developed by Charnes et al. (1978). This approach has been used in many studies on the developing and emerging economies (Denizer et al., 2000; Sathye, 2001; Isik and Hassan, 2002; Rezvanian and Mehdian, 2002; Toçi, 2009); it is considered the best approach for this type of macroeconomic environment (Grigorian and Manole, 2002).

There are several reasons for which the Data Envelopment Analysis approach has been chosen in this study. The main reason is that DEA can perform well with just a small number of observations; this is an important factor as we want to be able to calculate the efficiency separately for each year in order to underline the effects of 
regulatory changes and the implementation of financial innovations. In this regard, our database is far more complete than most of the studies that use DEA for measuring banking efficiency. Also by using DEA, there are no explicit functional forms on the data and the analysis that can be performed well despite the assorted size of the banking institutions. The main disadvantage of this approach is represented by the fact that the analysis is very sensitive to outlying observations, this being the reason why some sensitivity tests were performed in our research.

Presented in the following paragraphs is a short description of the Data Envelopment Analysis. If it is assumed that there is data on $\mathrm{K}$ inputs and $\mathrm{M}$ outputs for each of $\mathrm{N}$ banks; for $i$ bank these are represented by the vectors $x_{i}$ and $y_{i}$, respectively. Let us call the $K \times N$ input matrix $-X$, and the $M \times N$ output matrix - $Y$. To measure the cost efficiency for each bank, a ratio of all outputs over all inputs is calculated, such as $\left(u / y_{i} / v / x_{i}\right)$ where $u$ is an $M \times 1$ vector of output weights and $\mathrm{v}$ is a $K \times 1$ vector of input weights. To select optimal weights, the following mathematical programming problem is specified:

$$
\begin{aligned}
& \max _{\mathrm{u}, \mathrm{v}}\left(\mathrm{u}^{\mid} \mathrm{y}_{\mathrm{i}} / \mathrm{v}^{\mid} \mathrm{x}_{\mathrm{i}}\right), \\
& u^{\prime} y_{j} / v^{\prime} x_{j} \leq 1, \quad j=1,2, \ldots, N,
\end{aligned}
$$

$$
u, v \geq 0
$$

The above formula has a problem of infinite solutions and therefore the constraint $v^{\prime} X_{i}=$ 1 is imposed, which leads to:

$$
\begin{aligned}
& \max _{\mu, \rho}\left(\mathrm{u}^{\mid} \mathrm{y}_{\mathrm{i}} / \mathrm{v}{ }^{\mid} \mathrm{x}_{\mathrm{i}}\right), \\
& \rho^{\prime} x_{i}=1, \\
& \mu^{\prime} y_{i}-\rho / x_{j} \leq 0, \quad j=1,2, \ldots, N, \\
& \mu, \rho \geq 0,
\end{aligned}
$$

where notation is changed from $u$ and $v$ to $\mu$ and $\rho$, respectively, in order to reflect transformation.

Using the duality in linear programming, an equivalent envelopment form of this problem can be derived:

$$
\begin{aligned}
& \min _{\theta}, \lambda \\
& -y_{i}+Y \lambda \geq 0,
\end{aligned}
$$

$\theta x_{i}-X \lambda \geq 0$,

$\lambda \geq 0$,

where $\theta$ is a scalar and $\lambda$ is a vector of $N \times 1$ constants. The value of $\theta$ obtained will be the efficiency score for the $i$ bank, which will range between 0 and 1 . It should be noted that the problem should be solved $N$ times, ones for each bank.

In order to calculate cost efficiency under assumption of variable returns to scale, we add the following convexity constraint:

$N 1 / \lambda=1$

In order to calculate allocative efficiency, we assume that $w_{\mathrm{i}}$ is a vector of input prices for the $i$ bank and solve the following minimization problem:

$$
\begin{aligned}
& \left.\min _{\lambda \mathrm{x}} \underset{i}{*} \mathrm{~W} \quad\right|_{\mathrm{i}} \mathrm{x} \quad{ }_{\mathrm{i}}^{*} \\
& -y_{i}+Y \lambda \geq 0, \\
& X_{i}^{*}-X \lambda \geq 0,
\end{aligned}
$$

$\lambda \geq 0$.

where $x_{i}^{*}$ is the cost-minimizing vector of input quantities for the $i$ bank, given the input prices $w_{\mathrm{i}}$ and the output levels $y_{\mathrm{i}}$.

In order to carry out our study, we had to choose the right nature of the banking activity. In other words, in the academic literature on the subject, there are two competing approaches regarding the nature of the banking activity, namely the production and the intermediation approaches (Sealey and Lindley, 1977). We consider that the main function of a bank is to intermediate funds between depositors and borrowers at the lowest reachable cost, and thus we have chosen for our study the intermediation approach (see also: Gilbert and Wilson, 1998; Kraft and Tirtiroglu, 1998; Rezvanian and Mehdian, 2002; Isik and Hassan, 2002; Dardac and Boitan, 2008).

The Data Envelopment Analysis approach has allowed us to calculate the overall cost, technical, allocative, pure technical and scale efficiency. Thus, technical efficiency (TE) represents the ability of a bank to 
obtain maximum outputs at a given level of inputs or to use a minimal level of inputs to obtain a given level of outputs. The allocative efficiency (AE) represents the ability of a bank to select the optimal mix of inputs at a certain level of prices in order to be able to produce a given level of outputs. The overall cost efficiency (CA) represents the product of the technical and allocative efficiency. Also, the technical efficiency can be decompressed into scale efficiency (SE) and pure technical efficiency (PTE).

Table 1: Summary Statistics of the Variables Employed in the DEA Model (in Millions of RON)

\begin{tabular}{|c|c|c|c|c|}
\hline & \multicolumn{2}{|c|}{ Domestic } & \multicolumn{2}{|c|}{ Foreign } \\
\hline & Mean & $\begin{array}{l}\text { Standard } \\
\text { deviation }\end{array}$ & Mean & $\begin{array}{l}\text { Standard } \\
\text { deviation }\end{array}$ \\
\hline \multicolumn{5}{|l|}{2002} \\
\hline Number of banks & 8 & & 12 & \\
\hline \multicolumn{5}{|l|}{ Outputs } \\
\hline Loans & 881,961 & 2030,853 & 659,625 & 917,092 \\
\hline $\begin{array}{l}\text { Government } \\
\text { Securities }\end{array}$ & 325,048 & 521,370 & 278,817 & 575,585 \\
\hline Off-balance items & 485,843 & 1258,723 & 357,183 & 522,171 \\
\hline \multicolumn{5}{|l|}{ Inputs } \\
\hline Deposits & 2230,671 & 4620,985 & 1110,567 & 1631,886 \\
\hline Fixed assets & 312,424 & 669,191 & 122,217 & 303,955 \\
\hline Labor & 3250,750 & 5147,790 & 844,250 & 1378,270 \\
\hline \multicolumn{5}{|l|}{ Prices of inputs } \\
\hline Price of deposits & 0,204 & 0,199 & 0,124 & 0,105 \\
\hline Price of fixed assets & 3,879 & 6,772 & 4,634 & 6,939 \\
\hline Price of labor & 0,042 & 0,034 & 0,044 & 0,028 \\
\hline \multicolumn{5}{|l|}{2005} \\
\hline Number of banks & 8 & & 18 & \\
\hline \multicolumn{5}{|l|}{ Outputs } \\
\hline Loans & 2833,952 & 5550,322 & 1677,317 & 2523,307 \\
\hline $\begin{array}{l}\text { Government } \\
\text { Securities }\end{array}$ & 453,429 & 555,117 & 305,989 & 594,384 \\
\hline Off-balance items & 1041,615 & 2439,686 & 527,850 & 803,335 \\
\hline \multicolumn{5}{|l|}{ Inputs } \\
\hline Deposits & 4034,937 & 7502,325 & 2183,183 & 3785,699 \\
\hline Fixed assets & 325,137 & 622,455 & 134,767 & 256,342 \\
\hline Labor & 3543,250 & 4812,780 & 1203,556 & 1659,472 \\
\hline \multicolumn{5}{|l|}{ Prices of inputs } \\
\hline Price of deposits & 0,098 & 0,133 & 0,055 & 0,026 \\
\hline Price of fixed assets & 1,061 & 2,708 & 1,131 & 2,662 \\
\hline Price of labor & 0,041 & 0,020 & 0,047 & 0,023 \\
\hline \multicolumn{5}{|l|}{2009} \\
\hline Number of banks & 4 & & 21 & \\
\hline \multicolumn{5}{|l|}{ Outputs } \\
\hline Loans & 5592,500 & 5620,508 & 7934,728 & 11931,496 \\
\hline $\begin{array}{l}\text { Government } \\
\text { Securities }\end{array}$ & 1049,950 & 1144,739 & 837,876 & 902,762 \\
\hline Off-balance items & 1171,950 & 1049,690 & 2059,594 & 3366,076 \\
\hline \multicolumn{5}{|l|}{ Inputs } \\
\hline Deposits & 7832,100 & 7680,026 & 6360,233 & 9599,049 \\
\hline Fixed assets & 328,200 & 370,876 & 254,626 & 430,605 \\
\hline Labor & 3765,250 & 3098,893 & 2239,248 & 2743,989 \\
\hline \multicolumn{5}{|l|}{ Prices of inputs } \\
\hline Price of deposits & 0,059 & 0,036 & 0,078 & 0,034 \\
\hline Price of fixed assets & 0,301 & 0,191 & 0,381 & 0,630 \\
\hline Price of labor & 0,084 & 0,070 & 0,070 & 0,029 \\
\hline
\end{tabular}

Source: author's calculations 


\section{Data}

The data that we have used in our research is focused on the Romanian banks with the researched period being between 2002 and 2009. The balance sheet and income statements are taken from Bankscope a Bureau van Dijk database and the annual reports of the banks from our panel. Our original sample of banks encompassed approximately $87 \%$ of the total assets of the Romanian banking system, making our panel one of the most comprehensive upto-date. We have excluded from our panel the banks that are not engaged in universal banking model activities which characterises the Romanian banking system (e.g. Porsche Bank, Raiffeisen Housing Bank, BCR Banca pentru Locuințe) and also the banks for which the employment data were missing. As we have chosen to use the Data Envelopment Analysis, we have also excluded from our sample the banks whose prices were below or above $1 \%$ or $99 \%$, being a known fact that this type of analysis is very sensitive to outliers.

Using the intermediation approach, we have specified three inputs (capital, labour and deposits) and three outputs (loans, government securities and off-balance sheet items) for each of the banks from our panel. The variables used in our research are measured in millions of RON, except of course for labour which is measured in number of employees. In order to be able to ensure a qualitative comparability of the loan portfolios, we have subtracted from the total loans the loan loss provisions (see Grigorian and Manole, 2002). We have chosen to use government securities as private securities holdings tended to be negligible in the balance sheets of the Romanian banks, mainly because of the underdeveloped capital market. To be able to calculate the allocative efficiency, we have calculated the prices of our inputs. The price of capital is calculated as fixed assets revaluations divided by fixed assets. The price of labour is calculated by dividing total expenditures on wages, salaries and employees benefits by the total number of employees. The price of deposits is compounded as total interest expenses divided by the total amount of deposits.

In Table 1 we have summarised separately the statistics for the inputs, outputs and the prices of inputs for foreign and domestic banks. If we analyse carefully the obtained results we can draw a few quick conclusions. First, there is a growth of the average size of foreign banks in the analysed period. This can be attributed partially to the fact that foreign banks benefited from cheap financing lines from their controlling units and also because in 2006 the largest bank in Romania was privatised. Second, the portfolios of foreign and domestic banks have different compositions. The foreign banks tend to hold more loans, while the domestic banks prefer to invest more on government securities. Nevertheless, domestic banks tend to be more actively engaged in offbalance sheet transactions, at least until 2006, when, as a result of the economic boom previous to the crisis, foreign banks extended also their activities in this market beyond traditional banking operations.

Contrary to the evidence from the researches undertaken in the case of other countries (Isik and Hassan, 2002), foreign banks in Romania tended to have a lower price of deposits than domestic banks until 2007, afterwards the prices were equal or even higher. This can be attributed to the fact that foreign banks, starting with 2007 and the depreciation of the international financial landscape, had to pay-out their external loans and were in need of liquidities, being ready to pay out a higher price in order to attract resources from local depositors. Still, this is not very surprising taking into account the characteristics of the Romanian banking system. Most of the foreign banks present here have acquired a large deposits market share through the acquisition of local banks in the privatisation process. Generally these foreign banks are owned by reputable international banking conglomerates which provide in the eyes of the depositors additional insurances regarding the safety of their money. 
This idea is sustained by the research of Wagner and Iakova (2001) which consider that a high presence of foreign banks provides additional protections against capital flights and depositor runs.

Also in Table 1, we underline the significant differences that exist between the foreign and domestic banks regarding the price of their other two inputs, respectively labour and capital. The fact that foreign banks tend to pay a higher price for labour can be attributed partially to the fact that the top management of these banks consist mostly of foreign professionals, who are additionally rewarded for the fact that they have to work abroad but also to the human resources policy of these institutions which have the tendency to offer higher salaries in order to attract a more qualified staff. The situation changed once the financial turbulences started as foreign banks were the first ones to cut costs and implicitly reduce their personal expenses (e.g. freezing of cutting salaries, suspending bonuses). Foreign banks also have the tendency to pay a higher price for capital as they rely more on state-of-the-art technologies, which are never cheap to acquire and maintain. The domestic banks have started also to follow this trend, providing this way a plausible explanation for the equalisation of prices toward the end of the analysed period. 
Table 2: The Summary of the Mean Efficiency Measures Calculated Relative to Separate and Common Frontiers for the Years 2002-2009

\begin{tabular}{|c|c|c|c|c|}
\hline & \multicolumn{2}{|c|}{ Separate frontiers } & \multicolumn{2}{|c|}{ Common frontiers } \\
\hline & Domestic & Foreign & Domestic & Foreign \\
\hline \multicolumn{5}{|l|}{2002} \\
\hline $\mathrm{CE}$ & 0,749 & 0,661 & 0,408 & 0,656 \\
\hline $\mathrm{AE}$ & 0,789 & 0,782 & 0,726 & 0,779 \\
\hline TE & 0,940 & 0,839 & 0,546 & 0,836 \\
\hline PTE & 0,984 & 0,917 & 0,707 & 0,916 \\
\hline SE & 0,955 & 0,913 & 0,816 & 0,911 \\
\hline \multicolumn{5}{|l|}{2003} \\
\hline $\mathrm{CE}$ & 0,775 & 0,530 & 0,310 & 0,530 \\
\hline $\mathrm{AE}$ & 0,844 & 0,794 & 0,659 & 0,800 \\
\hline $\mathrm{TE}$ & 0,918 & 0,636 & 0,430 & 0,624 \\
\hline PTE & 0,924 & 0,837 & 0,625 & 0,739 \\
\hline SE & 0,993 & 0,756 & 0,704 & 0,843 \\
\hline \multicolumn{5}{|l|}{2004} \\
\hline $\mathrm{CE}$ & 0,699 & 0,495 & 0,422 & 0,493 \\
\hline$\overline{\mathrm{AE}}$ & 0,730 & 0,676 & 0,662 & 0,744 \\
\hline $\mathrm{TE}$ & 0,924 & 0,721 & 0,570 & 0,646 \\
\hline PTE & 0,978 & 0,898 & 0,684 & 0,781 \\
\hline SE & 0,944 & 0,816 & 0,863 & 0,852 \\
\hline \multicolumn{5}{|l|}{2005} \\
\hline $\mathrm{CE}$ & 0,723 & 0,534 & 0,341 & 0,531 \\
\hline$\overline{\mathrm{AE}}$ & 0,836 & 0,748 & 0,696 & 0,810 \\
\hline TE & 0,861 & 0,703 & 0,456 & 0,636 \\
\hline PTE & 0,974 & 0,815 & 0,603 & 0,763 \\
\hline SE & 0,886 & 0,868 & 0,779 & 0,838 \\
\hline \multicolumn{5}{|l|}{2006} \\
\hline$\overline{C E}$ & 0,808 & 0,588 & 0,470 & 0,584 \\
\hline$\overline{\mathrm{AE}}$ & 0,903 & 0,768 & 0,883 & 0,800 \\
\hline TE & 0,892 & 0,738 & 0,520 & 0,706 \\
\hline PTE & 0,903 & 0,849 & 0,591 & 0,819 \\
\hline SE & 0,987 & 0,870 & 0,866 & 0,860 \\
\hline \multicolumn{5}{|l|}{2007} \\
\hline $\mathrm{CE}$ & 0,794 & 0,512 & 0,348 & 0,506 \\
\hline $\mathrm{AE}$ & 0,880 & 0,772 & 0,858 & 0,782 \\
\hline TE & 0,889 & 0,619 & 0,376 & 0,607 \\
\hline PTE & 0,934 & 0,799 & 0,504 & 0,791 \\
\hline SE & 0,953 & 0,770 & 0,781 & 0,764 \\
\hline \multicolumn{5}{|l|}{2008} \\
\hline$\overline{C E}$ & 0,640 & 0,492 & 0,382 & 0,470 \\
\hline$\overline{\mathrm{AE}}$ & 0,729 & 0,793 & 0,818 & 0,806 \\
\hline TE & 0,857 & 0,606 & 0,421 & 0,559 \\
\hline PTE & 0,948 & 0,808 & 0,482 & 0,784 \\
\hline SE & 0,904 & 0,772 & 0,812 & 0,737 \\
\hline \multicolumn{5}{|l|}{2009} \\
\hline$\overline{C E}$ & 0,764 & 0,601 & 0,380 & 0,395 \\
\hline$\overline{\mathrm{AE}}$ & 0,905 & 0,798 & 0,805 & 0,689 \\
\hline TE & 0,840 & 0,739 & 0,450 & 0,570 \\
\hline PTE & 0,860 & 0,842 & 0,522 & 0,794 \\
\hline SE & 0,973 & 0,883 & 0,856 & 0,744 \\
\hline \multicolumn{5}{|l|}{ All } \\
\hline$\overline{\mathrm{CE}}$ & 0,744 & 0,552 & 0,382 & 0,520 \\
\hline $\mathrm{AE}$ & 0,827 & 0,766 & 0,763 & 0,776 \\
\hline $\mathrm{TE}$ & 0,890 & 0,700 & 0,471 & 0,648 \\
\hline PTE & 0,938 & 0,846 & 0,590 & 0,798 \\
\hline SE & 0,949 & 0,831 & 0,810 & 0,819 \\
\hline
\end{tabular}

CE - Cost Efficiency, AE - Allocative Efficiency, TE - Technical Efficiency, PTE - Pure Technical Efficiency, SE - Scale Efficiency. Source: author's calculations 


\section{Empirical Findings}

In order to analyse the efficiency of the Romanian banks during the chosen period, we have calculated the cost, allocative, technical, pure and scale efficiency using the Data Envelopment Analysis approach. In order to have a more comprehensive view of the problem, the efficiency of the domestic and foreign banks has been estimated relative to their separate frontier and then relative to a common frontier.

In Table 2, the results of the undertaken analyses have been summarized. With regard to the mean efficiency of the banks from our panel, we found that the value is slightly lower than the one registered in previous studies (Grigorian and Manole, 2002). This result can be attributed to the fact that our sample of banks has been much larger than the one from previous studies, including also a series of smaller banks. Also, the analysed period from our research is different and covers the first effects of the economic and financial downturn.

Even if when we take into account the separate frontier, the domestic banks seem to be more efficient than the foreign banks, if we correlate these results with the results obtained when using a common frontier, it can be argued that domestic banks are more inefficient than foreign banks, the first case underlying just the fact that these banks are having a very close inefficiency level. The differences in efficiency between foreign and domestic banks are very high, this being the reason why we have conducted also a series of tests in order to determine whether the banks come from the same population. Using a similar approach to other studies undertaken on the subject (e.g. Isik and Hassan, 2002), we have performed a series of parametric (t-test) and non-parametric (Wilcoxon Rank-Sum, Kruskal-Wallis and Kolmogorov-Smirnov) tests in order to accept or reject the null hypothesis that all the banks from our panel come from the same population. Table 3 summarises the results of our tests. The tests that we have applied cannot reject the null hypothesis at the $5 \%$ significance level, thus it will be appropriate to pull all the banks into one sample. These results, although not completely in line with the academic literature on the subject (Havrylchyk, 2005), are not singular (e.g. Sathye, 2001; Isik and Hassan, 2002). 
Table 3: Summary of Parametric and Non-Parametric Tests of the Hypothesis That Domestic and Foreign Banks Come from the Same Distribution

\begin{tabular}{|c|c|c|c|c|c|c|c|c|}
\hline & \multicolumn{2}{|c|}{ Name of the test } & & & & & & \\
\hline & \multicolumn{2}{|c|}{ t-test } & \multicolumn{2}{|c|}{$\begin{array}{c}\text { Wilcoxon } \\
\text { Rank-Sum test }\end{array}$} & \multicolumn{2}{|c|}{ Kruskal-Wallis test } & \multicolumn{2}{|c|}{$\begin{array}{c}\text { Kolmogorov-Smirnov } \\
\text { test }\end{array}$} \\
\hline $\begin{array}{l}\text { Test } \\
\text { statistics }\end{array}$ & \multicolumn{2}{|c|}{$t($ prob $>t)$} & \multicolumn{2}{|c|}{$\mathrm{z}($ prob $>\mathrm{z})$} & \multicolumn{2}{|c|}{$\chi^{2}\left(\right.$ prob $\left.>\chi^{2}\right)$} & \multicolumn{2}{|c|}{$\mathrm{D}($ prob $>\mathrm{D})$} \\
\hline \multicolumn{9}{|l|}{2002} \\
\hline $\mathrm{CE}$ & 1,992 & $(0,062)$ & 1,929 & $(0,054)$ & 3,871 & $(0,049)$ & 1,187 & $(0,120)$ \\
\hline $\mathrm{AE}$ & 0,501 & $(0,623)$ & 0,309 & $(0,758)$ & 0,121 & $(0,729)$ & 0,548 & $(0,925)$ \\
\hline TE & 2,997 & $(0,008)$ & 2,199 & $(0,028)$ & 5,006 & $(0,025)$ & 1,369 & $(0,047)$ \\
\hline PTE & 2,308 & $(0,033)$ & 1,697 & $(0,090)$ & 3,013 & $(0,083)$ & 1,187 & $(0,120)$ \\
\hline SE & 1,089 & $(0,291)$ & 1,273 & $(0,203)$ & 1,720 & $(0,190)$ & 0,913 & $(0,375)$ \\
\hline \multicolumn{9}{|l|}{2003} \\
\hline $\mathrm{CE}$ & 1,546 & $(0,138)$ & 1,740 & $(0,082)$ & 3,149 & $(0,076)$ & 1,209 & $(0,108)$ \\
\hline $\mathrm{AE}$ & 1,263 & $(0,221)$ & 1,263 & $(0,207)$ & 1,682 & $(0,195)$ & 1,048 & $(0,222)$ \\
\hline TE & 1,653 & $(0,114)$ & 1,877 & $(0,061)$ & 3,652 & $(0,056)$ & 1,209 & $(0,108)$ \\
\hline PTE & 1,009 & $(0,325)$ & 0,921 & $(0,357)$ & 0,913 & $(0,339)$ & 0,766 & $(0,601)$ \\
\hline SE & 1,529 & $(0,142)$ & 1,365 & $(0,172)$ & 1,958 & $(0,162)$ & 1,048 & $(0,222)$ \\
\hline \multicolumn{9}{|l|}{2004} \\
\hline $\mathrm{CE}$ & 0,521 & $(0,607)$ & 0,641 & $(0,522)$ & 0,449 & $(0,503)$ & 0,772 & $(0,591)$ \\
\hline $\mathrm{AE}$ & 0,600 & $(0,554)$ & 0,990 & $(0,322)$ & 1,039 & $(0,308)$ & 0,772 & $(0,591)$ \\
\hline TE & 0,716 & $(0,481)$ & 0,757 & $(0,449)$ & 0,618 & $(0,432)$ & 0,532 & $(0,940)$ \\
\hline PTE & 0,849 & $(0,405)$ & 0,903 & $(0,367)$ & 0,869 & $(0,351)$ & 0,652 & $(0,789)$ \\
\hline SE & $-0,136$ & $(0,893)$ & 0,146 & $(0,884)$ & 0,031 & $(0,861)$ & 0,480 & $(0,975)$ \\
\hline \multicolumn{9}{|l|}{2005} \\
\hline $\mathrm{CE}$ & 1,573 & $(0,129)$ & 1,889 & $(0,059)$ & 3,674 & $(0,055)$ & 1,079 & $(0,195)$ \\
\hline $\mathrm{AE}$ & 1,178 & $(0,250)$ & 0,500 & $(0,617)$ & 0,279 & $(0,598)$ & 0,490 & $(0,970)$ \\
\hline TE & 1,708 & $(0,101)$ & 1,972 & $(0,049)$ & 4,000 & $(0,046)$ & 1,209 & $(0,107)$ \\
\hline PTE & 1,565 & $(0,131)$ & 1,305 & $(0,192)$ & 1,778 & $(0,182)$ & 1,046 & $(0,224)$ \\
\hline SE & 0,667 & $(0,511)$ & 0,553 & $(0,580)$ & 0,339 & $(0,560)$ & 0,654 & $(0,786)$ \\
\hline \multicolumn{9}{|l|}{2006} \\
\hline $\mathrm{CE}$ & 0,794 & $(0,435)$ & 1,053 & $(0,292)$ & 1,182 & $(0,277)$ & 1,000 & $(0,270)$ \\
\hline $\mathrm{AE}$ & $-0,737$ & $(0,469)$ & 0,442 & $(0,659)$ & 0,226 & $(0,634)$ & 0,600 & $(0,864)$ \\
\hline TE & 1,599 & $(0,123)$ & 1,630 & $(0,103)$ & 2,770 & $(0,096)$ & 1,100 & $(0,178)$ \\
\hline PTE & 2,225 & $(0,036)$ & 1,766 & $(0,077)$ & 3,241 & $(0,072)$ & 1,100 & $(0,178)$ \\
\hline SE & $-0,082$ & $(0,935)$ & 0,102 & $(0,919)$ & 0,018 & $(0,892)$ & 0,500 & $(0,964)$ \\
\hline \multicolumn{9}{|l|}{2007} \\
\hline $\mathrm{CE}$ & 0,999 & $(0,328)$ & 1,223 & $(0,221)$ & 1,580 & $(0,209)$ & 1,000 & $(0,270)$ \\
\hline $\mathrm{AE}$ & $-0,726$ & $(0,475)$ & 0,679 & $(0,497)$ & 0,509 & $(0,476)$ & 0,700 & $(0,711)$ \\
\hline TE & 1,613 & $(0,120)$ & 1,597 & $(0,110)$ & 2,658 & $(0,103)$ & 1,100 & $(0,178)$ \\
\hline PTE & 0,120 & $(0,026)$ & 1,630 & $(0,103)$ & 2,770 & $(0,096)$ & 1,000 & $(0,270)$ \\
\hline SE & $-0,131$ & $(0,897)$ & 0,034 & $(0,973)$ & 0,005 & $(0,946)$ & 0,400 & $(0,997)$ \\
\hline \multicolumn{9}{|l|}{2008} \\
\hline $\mathrm{CE}$ & 0,535 & $(0,598)$ & 0,889 & $(0,374)$ & 0,859 & $(0,354)$ & 0,851 & $(0,464)$ \\
\hline $\mathrm{AE}$ & $-0,126$ & $(0,901)$ & 0,074 & $(0,941)$ & 0,012 & $(0,912)$ & 0,502 & $(0,963)$ \\
\hline $\mathrm{TE}$ & 0,922 & $(0,366)$ & 1,186 & $(0,236)$ & 1,496 & $(0,221)$ & 1,026 & $(0,244)$ \\
\hline PTE & 2,218 & $(0,037)$ & 1,816 & $(0,069)$ & 3,434 & $(0,064)$ & 1,375 & $(0,046)$ \\
\hline SE & $-0,545$ & $(0,591)$ & 0,222 & $(0,824)$ & 0,067 & $(0,795)$ & 0,502 & $(0,963)$ \\
\hline \multicolumn{9}{|l|}{2009} \\
\hline $\mathrm{CE}$ & 0,118 & $(0,907)$ & 1,038 & $(0,299)$ & 1,155 & $(0,283)$ & 0,938 & $(0,342)$ \\
\hline $\mathrm{AE}$ & $-1,326$ & $(0,198)$ & 1,112 & $(0,266)$ & 1,320 & $(0,251)$ & 0,938 & $(0,342)$ \\
\hline $\mathrm{TE}$ & 0,829 & $(0,416)$ & 0,927 & $(0,354)$ & 0,929 & $(0,335)$ & 0,829 & $(0,497)$ \\
\hline PTE & 1,926 & $(0,067)$ & 1,260 & $(0,208)$ & 1,683 & $(0,195)$ & 0,917 & $(0,370)$ \\
\hline SE & $-0,845$ & $(0,407)$ & 0,852 & $(0,394)$ & 0,791 & $(0,373)$ & 0,655 & $(0,785)$ \\
\hline
\end{tabular}

* The t-test is a parametric test that tests the null hypothesis, that foreign and domestic banks have the same mean; Wilcoxon Rank-Sum, Kruskal-Wallis are non-parametric tests that test the shift in the location of the distribution; Kolmogorov-Smirnov is a non-parametric test that tests the hypothesis of the equality of the distributions.

Source: author's calculations 
As mentioned before, foreign banks tend to manifest a higher cost efficiency average (52\%) than their domestic peers $(38,2 \%)$. These results suggest that foreign banks have succeeded in utilizing their superior know-how and expertise in order to compensate the potential disadvantages of not knowing the local market. These results are in line with other researches undertaken on this subject (Bhattacharyya et al., 1997; Kraft and Tirtiroglu, 1998; Isik and Hassan, 2002; Grigorian and Manole, 2002; Hasan and Marton, 2003).

In our approach, we have split the cost efficiency into technical and allocative components. The results summarised in Table 2 underline the fact that there is a sufficient room for the improvement of the allocative efficiency. The high level of allocative inefficiency can be related to the fluctuation of the inflation rate during the analysed period that leads to a high fluctuation of the input prices, which prevented the management in developing long-term plans.

It is further observed that the allocative inefficiency is lower than the technical inefficiency, which suggests that the dominant source of the cost inefficiency is technical rather than allocative. The higher technical inefficiency relative to allocative inefficiency implies that the managers of foreign Romanian banks were relatively good at choosing the proper input mix given the prices, but they were not that good at utilising all factor inputs. Hence, overall inefficiency in foreign Romanian banks may be attributed, to a greater extent, to underutilising or wasting of resources rather than choosing the incorrect input mix.

Between the years 2002 and 2009, the efficiency of banks, both domestic and foreign, did not improve but more over it has been diminished on average. If Table 2 is examined, it becomes evident that efficiency declined between the years 2006 and 2009 by approximately 19,1\% for domestic banks and $32,4 \%$ for foreign banks, mainly as an effect of the financial and economic downturn.
Another reason for the failure of Romanian banks to improve their efficiency can be attribute to the rapid growth of certain types of loans and also to a $\mathrm{V}$ shape evolution of the non-performing loans in the analysed period. Throughout the research period, the structure of the overall banking assets has gone through a drastic change. As previous cheap sources of income such as Government bonds and loans to state companies were exhausted, most of the banks had to tap different segments of the market, through giving loans to individuals and especially with consumer credit becoming the new focus point of the banks. The banking assets escalated in this period in Romania, with consumer credit registering a compound annual growth rate (CAGR) of 54\% (NBR, 2010).

As the assets of banks grew at a very high rate and the overall macroeconomic environment depreciated starting with 2007, the management of these institutions faced problems in controlling costs and risks, and as a result of these, the share of the non-performing loans, after a period of stabilisation between 2002 and 2005, in which the share dropped from $9,2 \%$ to $2,6 \%$, grew sharply to $15,3 \%$ at the end of 2009 (Word Bank, 2010).

Further, we have disentangled technical efficiency into scale efficiency and pure technical efficiency. After the elimination of the scale factor, it can be observed that banks registered a higher technical efficiency. Thus, foreign banks exhibit a pure technical efficiency of about 79,8\% while their domestic peers managed to reach only a $59 \%$ average. The values registered by the foreign banks are comparable with the ones registered by the developed economies.

\section{Conclusions}

The current research has investigated whether foreign banks, which tend to benefit from the experience and superior know-how of their parent banks, are more efficient than domestic banks, in the case of the Romanian banking sector, during the period 2002-2009. 
We have chosen the Data Envelopment Analysis approach which has enabled us to distinguish between five types of efficiency; namely, cost, allocative, technical, pure technical and scale. In addition to this, we have run also some parametric and nonparametric tests in order to establish if the foreign and domestic banks which operate in Romania are coming from the same population.

The results underline that the average efficiency of foreign banks is $52 \%$ while the efficiency of their domestic peers is only $38,2 \%$. Having deepened the analysis and splitted the cost efficiency into allocative and technical efficiency, we were able to underline the fact that the overall higher efficiency of foreign banks is the direct result of their ability to obtain a higher productivity of their inputs (technical efficiency), rather than making superior decision by choosing the right mix of inputs at a given price level (allocative efficiency). Our parametric and non-parametric tests were unable to reject the null hypothesis and thus foreign and domestic banks are sharing a common frontier. During the researched period, the efficiency of the banking sector has not been improved. Moreover, the period between 2007 and 2009 registered the highest decline in efficiency which can be attributed to the depreciation of the macroeconomic environment as a result of the financial and economic downturn.

One of the future research directions that have been identified is represented by the study of the way in which the efficiency of the banking sector from other new EU member states from Central and Eastern Europe have been affected by the EU ascension process before and during the current financial and economic crisis.

\section{Acknowledgment}

I hereby acknowledge the support of the "Alexandru Ioan Cuza" University of Iasi, in the development of this article through the grant POSDRU/88/1.5/S/47646, entitled "Studii doctorale: portal spre o carieră de excelență în cercetare şi societatea cunoaşterii", co-financed through the
European Social Fund, within the Sector Operational Programme Human Resources Development 2007-2013.

\section{References}

Altunbas, Y., Liu, M. H., Molyneux, P. \& Seth, R. (2000)."Efficiency and Risk in Japanese Banking," Journal of Banking and Finance, 24, 1605-1628.

Angelidis, D. \& Lyroudi, K. (2006). 'Efficiency in the Italian Banking Industry: Data Envelopment Analysis and Neural Networks,' International Research Journal of Finance and Economics, 5.

Aydin, N., Yalama, A. \& Sayim, M. (2009). 'Banking Efficiency in Developing Economy: Empirical Evidence From Turkey,' Journal of Money, Investment and Banking, 8, 50-70.

Berger, A. N., De young, R., Genay, H. \& Udell, G. F. (2000)."Globalization of Financial Institutions: Evidence from Cross-Border Banking Performance," Brookings-Wharton Papers on Financial Services, 3, 23-158.

Berger, A. N. \& Humphrey, D. B. (1997)."Efficiency of Financial Institutions: International Survey and Directions for Future Research," European Journal of Operational Research, 98, 175-212.

Berger, A. N. \& Mester, L. J. (1997)."Inside the Black Box: What Explains Differences in the Efficiencies of Financial Institutions?," Journal of Banking and Finance, 21, 895947.

Bonin, J. P., Hasan, I. \& Wachtel, P. (2005)."Bank Performance, Efficiency and Ownership in Transition Countries," Journal of Banking and Finance, 29, 31-53.

Brissimis, S. N., Delis, M. D. \& Tsionas, E. M. (2006)."Technical and Allocative Efficiency in European Banking," Working Paper Bank of Greece, 46.

Charnes, A., Cooper, W. W. \& Rhoads, E. (1978)."Measuring the Efficiency of Decision Making Units," European Journal of Operational Research, 2, 429-444. 
Chu, S. F. \& Lim, G. H. (1998)."Share Performance and Profit Efficiency of Banks in an Oligopolistic Market: Evidence from Singapore," Journal of Multinational Financial Management, 8, 155-168.

Claessens, S., Demirguc-Kunt, A. \& Huizinga, H. (2001)."How Does Foreign Entry Effect Domestic Banking Markets?," Journal of Banking and Finance, 25, 891-911.

Clarke, G. R. G., Cull, R., Peria, M. S. M. \& Sanchez, S. M. (2001). Foreign Bank Entry: Experience, Implications for Developing Countries and Agenda for Further Research, World Bank Working Paper, 2698.

Dardac, N. \& Boitan, I. A. (2008)."Evaluation of Individual and Aggregate Credit Institutions Management's Performance," Economie Teoretică Și Aplicată, 5 (522).

Debasish, S. S. (2006)."Efficiency Performance in Indian Banking - Use of Data Envelopment Analysis," Global Business Review, 7, 325- 333.

Denizer, C. A., Dinc, M. \& Tarimcilar, M. (2000). Measuring Banking Efficiency in the Pre- and Post-liberalisation Environment: Evidence from the Turkish Banking System, World Bank Working Paper, 2476.

Goddard, J. A., Molyneux, P. \& Wilson, J. O. S. (2001). European Banking: Efficiency, technology, and growth, Wiley, New York.

Grigorian, D. A. \& Manole, V. (2002). Determinants of Commercial Bank Performance in Transition: an Application of Data Envelopment Analysis, IMF Working Paper, 146 (2).

Hardy, D. C. \& Bonaccorsi Di Patti, E. (2001). Bank Reform and Bank Efficiency in Pakistan, IMF Working Paper, 138(1).

Hasan, I. \& Marton, K. (2003)."Development and Efficiency of the Banking Sector an a Transitional Economy: Hungarian Experience," Journal of Banking and Finance, 27, 2249-2271.
Havrylchk, O. (2005)."Eficiency of the Polish Banking Industry: Foreign Versus Domestic Banks," Journal of Banking and Finance, 30, 1975-1996.

Isik, I. \& Hassan, M. K. (2002)."Technical, Scale and Allocative Efficiencies of Turkish Banking Industry," Journal of Banking and Finance, 26, 719-766.

Kraft, E. \& Tirtiroglu, D. (1998)."Bank Efficiency in Croatia: a Stochastic-Frontier Analysis," Journal of Comparative Economics, 26, 282-300.

Mertens, A. \& Urga, G. (2001)."Efficiency, Scale and Scope Economies in the Ukrainian Banking Sector in 1998," Emerging Markets Review, 3(2), 292-308.

National Bank of Romania, Activity Reports between 1998 and 2010.

Rezvanian, R. \& Mehdian, S. (2002)."An Examination of Cost Structure and Production Performance of Commercial Banks in Singapore," Journal of Banking and Finance, 26, 79-98.

Sathye, M. (2001)."X-efficiency in Australian Banking: An Empirical Investigation," Journal of Banking and Finance, 25, 613-630.

Sealey, C. W. \& Lindley, J. T. (1977)."Inputs, Outputs, and a Theory of Production and Cost at Depository Financial Institutions," The Journal of Finance, 32 (4), 1251-1265.

Sufian, F. (2011)."Benchmarking the Efficiency of the Korean Banking Sector: a DEA Approach," Benchmarking: an International Journal, 18 (1), 107-127(21).

Sufian, F. \& Habibullah, M. S. (2010)."Developments in the Efficiency of the Thailand Banking Sector: a DEA Approach," International Journal of Development Issues, 9 (3), 226-245.

Thanassoulis, E. (2001). Introduction to the Theory and Application of Data Envelopment Analysis:A Foundation Text with Integrated Software, Kluwer Academic Publishers, Boston. 
Toçi, V. Z. (2009)."Efficiency of Banks in South-East Europe: with Special Reference to Kosovo," CBK Working Paper, 4.

Wagner, N. \& Iakova, D. (2001)."Financial Sector Evolution in the Central European Economies: Challenges in Supporting Macroeconomic Stability and Sustainable Growth," IMF Working Paper, 141 (1).
Weill, L. (2004)."Measuring Cost Efficiency in European Banking: a Comparison of Frontier Techniques," Journal of Productivity Analysis, 21, 133-152.

World Bank (2010). World Development Indicators 2010 Part 1 And 2, Washington. 